\title{
Üniversite öğrencilerinin yabancı dil öğrenme algıları: bir devlet üniversitesi örneği
}

\section{Emrah EKMEKÇí1}

\begin{abstract}
APA: Ekmekçi, E. (2019). Üniversite öğrencilerinin yabancı dil öğrenme algıları: bir devlet üniversitesi örneği. RumeliDE Dil ve Edebiyat Araştırmaları Dergisi, (17), 1-13. DOI: 10.2900o/rumelide.656143.
\end{abstract}

$\ddot{\mathbf{O} z}$

Öğrencilerin yabancı dile bakışları; yabancı dil öğrenme istekleri, amaçları, ihtiyaçları, önyargıları ve öğrenme ortamlarıyla oldukça yakından ilişkilidir. Yabancı dil öğrenenlerin yabancı dile bakış açılarını bilmenin yabancı dil öğretmenlerini ve araştırmacıları daha donanımlı hâle getireceği açıktır. Günümüzde yabancı dil öğrenmede karşılaşılan en önemli sorunlardan birinin motivasyon eksikliği olduğu da yapılan araştırmalarda ortaya konulmuştur. Dolayısıyla öğrencilerin yabancı dil algıları, tutumları, inançları, yabancı dile bakış açıları ve motivasyonları arasında bir ilişki olduğu düşünülmektedir. Bu çerçevede mevcut çalışma üniversite öğrencilerinin Türkiye'de yabancı dile bakış açılarının ortaya çıkarılmasını hedeflemektedir. Çalışmaya 2016-2017 akademik yılında bir devlet üniversitesinin farklı lisans programlarında hazırlık ve birinci sınıflarında öğrenim gören toplam 200 öğrenci katılmıştır. Likert tipi anket kullanılarak toplanan verilerin SPSS 20 programında betimleyici istatistikleri çıkarılmıştır. Toplam beş boyuttan oluşan araştırmada üniversite öğrencilerinin yabancı dile olan genel bakışı, yabancı dil öğreniminde ana dili kullanımına yönelik algıları, temel dil becerilerine olan bakış açıları, yabancı dil öğrenmede amaç ve olumlu tutumlarının olup olmadığı değerlendirilmiştir. Araştırma sonucunda üniversite öğrencilerinin büyük çoğunluğunun genel anlamda yabancı dile karşı olumlu bakış açısının olduğu, yabancı dili büyük oranda sınıf ortamında öğrendikleri, yabancı dil öğrenme sürecinde mümkün olduğunca Türkçeden yararlanma eğiliminde oldukları ve dil öğrenme motivasyonunu önemsedikleri ortaya çıkmıştır. Bunlara ilaveten araştırma sonucunda özellikle yabancı dilde konuşma ve yazma becerilerine karşı öğrencilerin önyargılı olup olumsuz bakış açısı geliştirdikleri belirlenmiştir. Ayrıca araştırmaya katılan öğrencilerin yarısından fazlasının yabancı dili öğrenmede dışsal motivasyona sahip oldukları sonucuna varılmıştır.

Anahtar kelimeler: Yabancı dil algısı, motivasyon, bakış açısı, tutum, inanç.

\section{University students' perceptions on foreign language learning: the case of a state university}

\begin{abstract}
Students' perceptions about a foreign language is closely related to their foreign language learning desires, aims, needs, prejudices, and learning environments. It is clear that knowing foreign language learners' perceptions towards foreign languages will make foreign language teachers and researchers more informed and equipped. Research has shown that one of the most important problems encountered in learning foreign languages is the lack of motivation. Therefore, it is thought that there is a connection between foreign language perceptions, attitudes, beliefs, foreign language

Doç. Dr., Ondokuz Mayıs Üniversitesi, Eğitim Fakültesi, Yabancı Diller Eğitimi Bölümü (Samsun, Türkiye), emrah.ekmekci@omu.edu.tr, ORCID ID: 0000-0001-5585-8512 [Makale kaylt tarihi: 18.09.2019-kabul tarihi: 20.12.2019; DOI: 10.29000/rumelide.656143]




\begin{abstract}
perspectives and motivations of students. In this context, the present study aims to reveal the university students' perspectives about foreign languages in Turkey. A total of 200 students studying in preparatory and first year classes at different undergraduate programs of a state university participated in the study in the 2016-2017 academic year. The collected data based on the Likert type questionnaire were analyzed through descriptive statistics in the SPSS 20 program. The survey, which consists of five dimensions, aims to find out students' general views about foreign languages, their perceptions of the native language use in foreign language learning, their perspectives on basic language skills, and their attitudes towards the foreign language learning. As a result of the research, it was found that the vast majority of the university students have a positive view towards the foreign languages in general, they tend to use Turkish language as much as possible in the foreign language learning process, and they attach importance to the language learning motivation. In addition to these, it has been determined that students are prejudiced against speaking and writing skills in foreign languages and developed a negative viewpoint. Moreover, it was revealed that over half of the students who participated in the survey had external motivation to learn a foreign language.
\end{abstract}

Keywords: Foreign language perception, motivation, viewpoint, attitude, belief.

\title{
1. Giriş
}

Günümüzde sanayi, ekonomi, kültür, siyasi vb. alanlardaki gelişmelerin beraberinde getirdiği bilgi paylaşımı ihtiyacındaki artışa paralel olarak yabancı dil bilmek son derece önemli hâle gelmiştir. Bu nedenle yabancı dil eğitimi tüm dünyada olduğu gibi Türkiye'de de üzerinde çokça durulan, kamuoyunda sıkça tartışma konusu olan ve üzerinde çokça bilimsel araştırma yapılan bir alan haline gelmiştir. Özellikle İngilizce öğretimi 1997 yılında ilkokul 4. sınıftan, 2012 yılında ise ilkokul 2. sınıftan başlatılıp ortaokul, lise ve üniversite eğitimi boyunca devam ettirilmiştir. İngilizcenin yanında, kısıtlı da olsa, Almanca ve Fransızca başta olmak üzere, okulların özelliğine ve niteliğine bağlı olarak, farklı yabancı dillerin eğitimleri verilmeye çalışılmaktadır. Ancak verilen yabancı dil eğitiminin niteliği, yabancı dil öğrenme süreçleri ve sonuçta varılan düşük yabancı dil yeterliliğinin nedenleri hemen hemen herkes tarafından sorgulanmış ama net cevaplar ortaya konulamamıştır. İlkokul, ortaokul ve lise düzeyinde verilen yaklaşı 1400 saatlik yabancı dil (büyük oranda İngilizce) eğitiminden sonra öğrencilerin \%90’ının hâlâ başlangıç seviyesinde kaldığı belirtilmektedir (Paker, 2012). Yabancı dil eğitiminde oluşan bu olumsuz durumlar üzerine birçok araştırma yapılmış ve çeşitli çözüm önerileri de ortaya koyulmuştur. Örneğin, Demirpolat (2015) yabancı dil eğitimindeki temel sorunları; yabancı dil öğretmenlerinin hizmet öncesi eğitimleriyle ilgili sorunlar, istihdam edilme biçimleriyle ilgili sorunlar, fiziksel şartlarla ilgili sorunlar, eğitim materyalleriyle ilgili sorunlar, öğretim yöntemleriyle ilgili sorunlar, yönetim ve denetimle ilgili sorunlar şeklinde başlıklar altında toplamış ve çeşitli çözüm önerilerinde bulunmuştur. Yabancı dil eğitiminde sorunlar ve çözüm önerilerine yönelik yapılan çalışmalar (Acat \& Demiral, 2002; Arslan \& Akbarov, 2010; Bayraktaroğlu, 2012; Bayyurt, 2012; Çimen, 2017; Can \& Işık Can, 2014; Haznedar, 2004, 2010; Işık, 2008; Kizildag 2009; Suna \& Durmuşçelebi, 2013; Ünal \& İlhan, 2017) genellikle motivasyon, yöntem, müfredat, dil politikası, planlama, fiziksel ortam, öğretmen eğitimi gibi kavramlara vurgu yapmıştır.

Yukarıda bahsedilen çalışmalarda üzerinde durulan sorunların yanında aslında yabancı dil öğrenme/öğretme sürecinde öğrenenlerin dil öğrenmeyle ilgili inançları, algıları ve dil öğrenmeye yönelik tutumları da oldukça önemlidir. Breen'e (2001) göre öğrencilerin sinıf ortamına getirdikleri dil öğrenimine yönelik inançlar öğrenme sürecine ve başarılarına önemli derecede etki etmektedir. Buradan hareketle son yıllarda yapılan araştırmaların da ortaya koyduğu gibi dil öğretiminde başarıya 
etki eden faktörlerin arasında bilişsel süreçlerin dikkate değer bir şekilde etkisi olduğu söylenebilir. Diğer bir deyişle yabancı dil öğrenme süreçleriyle ilgili belirli algı ve inançlara sahip olan bir kişi ister istemez bunu dil öğrenirken kullandığı stratejilere ve yöntemlere de yansıtacaktır. Kaçar ve Zengin'e (2009) göre dil öğrenenlerin dil öğrenme süreçleri ve doğasıyla ilgili inançları özel dil öğrenme stratejilerinin kullanımına etki etmektedir. Bu çerçevede dil öğrenenlerin inançları ve süreçle ilgili varsayımlarının bireysel farklılıklardan kaynaklanması olasıdır.

Bireysel farklılıklar göz önünde tutularak yabancı dil öğrenme sürecinde başarıya etki eden faktörler arasında tutum ve kaygı olduğu belirtilmektedir (Pan \& Akay, 2015). Öğrencilerin hedef dilde başarı elde edebilmeleri için öncelikle bu dile karşı olumlu tutum geliştirmeleri beklenir. Aynı şekilde olumsuz tutumlardan kaynaklı yabancı dil kaygısı ortaya çımakta, bireyin kendisiyle ve hedef dil ile ilgili olumsuz inançları ve algıları dil öğrenme sürecinde olumsuz etkiye neden olmaktadır (Horwitz, 1986).

Tüm bunlardan hareketle; yabancı dil öğrenme sürecinde öğrenenlerin yabancı dil ile ilgili algıları, motivasyonları, tutumları ve inançlarını bilmek süreç sonunda onların başarı ve başarısızlıklarının belirlenmesi ve öğrenim/öğretim sürecinin değerlendirilerek yeni planlamaların buna göre yapılması noktasında yarar sağlayacağı açıtır. Gerek öğrenme ve öğretme sürecine yönelik gerekse süreç öncesi öğrencilerin yabancı dile bakış açılarının belirlenmesi ülkedeki yabancı dil eğitim programlarının hazırlanması, dil politikası belirlenmesi, materyal hazırlama, planlama, vb. aşamalarda uzmanlara ve araştırmacılara ışık tutacaktır.

Bu bağlamda Türkiye'de yabancı dil öğrenenlerin yabancı dil ile ilgili algı ve bakış açılarını araştıran farklı çalışmalar yapılmıştır. Örneğin, Baştürk (2012) Balıkesir ilinde lise ve üniversite öğrencilerinin yabancı dil algılarını karşılaştırmalı olarak incelemiş ve öğrencilerin dil öğrenmeye karşı olumlu tutumlarının olduğu ancak süreç sonundaki algllarının olumsuz olduğu sonucuna varmıştır. Araştırmadan elde edilen diğer bir sonuç ise dil öğrenme motivasyonunun daha çok dişsal nedenlere bağlı olarak gerçekleşmesidir. Yaş, eğitim düzeyi ve ana dili etkisi gibi değişkenlerin incelendiği çalışmada lise ve üniversite öğrencilerinin yabancı dil algılarında çok önemli farklılıklar olmadığı ancak 14-18 yaş grubu öğrenenlerin ana dil kaynaklarını daha fazla kullandıkları belirlenmiştir. Baştürk (2012) araştırma sonucunda dil öğretiminde "parçalı dil anlayışı"nın devam ettiğini vurgulayarak şu şekilde bir çıkarım yapmıştır:

"Öğrenilmiş ve öğretilmiş bu anlayıştan "sistemik dil öğrenme" anlayışına geçilmesine ve dil öğrenmede paradigma değişikliğine gereksinim duyulmaktadır. Dil öğretiminde "yabancı dil” kavramından çok, "ikinci dil" kavramının kullanılması bu paradigma değişikliğinin temelini oluşturması açısından önemlidir.' (s. 268).

Baştürk (2012) özellikle 'ikinci dil edinimi' kavramına dikkat çekerek dil etkinliklerinin edinim odaklı olması gerektiğini savunmaktadır. Bu çalışma gibi dil öğrenenlerin algılarını ve bakış açılarını konu edinen bir diğer çalışma ise Akalın ve Zengin (2007) tarafından yapılmıştır. Araştırmacılar farklı illerden Atatürk Üniversitesi’ne İngilizce öğretmenliği lisans programı eğitimi almaya gelen öğretmen adayları aracılığıyla farklı yaş ve cinsiyetteki insanlara uygulanan Likert tipi anketle veri toplamışlardır. Yirmi bir sorudan oluşan anketten elde edilen verilerle Türk halkının yabancı dile olan algıları değişkenler arası ilişkilendirmeyle ortaya konulmaya çalışılmıştır. Yabancı dil öğrenen ya da öğrenmeye aday vatandaşların yabancı dile bakış açılarını bilmenin yabancı dil öğretmenlerini ve araştırmacıları daha donanımlı hâle getireceği de çalışmada ayrıca vurgulanmıştır. 
Öğrencilerin yabancı dile olan tutumlarının incelendiği bir diğer çalışmada ise, Karahan (2007) İngilizcenin yoğun olarak öğretildiği bir özel okulda uyguladığı anketten elde ettiği veriler ışığında; bu öğrencilerin genel anlamda orta düzeyde olumlu tutum sahibi olduklarını, öğrencilerin İngilizcenin önemini anlamakta, ancak İngilizceyi öğrenmek konusunda yüksek düzeyde istek göstermediklerini ortaya koymuştur. Karahan’ın (2007) sekizinci sınıf bağlamında yaptığı çalışmadan farklı olarak yükseköğretim bağlamında yabancı dile olan bakış açılarını araştıran bir başka çalışmada ise, Babanoğlu ve Ağçam (2016) sosyal ve fen bilimleri alanlarındaki lisans programlarında eğitim gören öğrencilerin yabancı dil algılarını karşılaştırmalı olarak incelemişlerdir. Araştırma sonucunda iki grup arasında yabancı dil algısına ilişkin herhangi anlamlı farkın olmadı̆̆ı sonucuna ulaşılmıştır.

Alanyazında Türkiye bağlamında yapılmış çalışmaların bir kısmının özetlendiği şu ana kadarki bahsedilen çalışmalarda da görüldüğü üzere, yabancı dil başarısı ve yabancı dile olan bakış açısı birbiriyle ilişkilidir. Ekmekçi (1983), öğrencilerin yabancı dildeki başarılarının, dil yeteneklerinden ya da o dile karşı tutumlarından kaynaklandığını ifade etmektedir. Diğer bir deyişle öğrencilerin yabancı dile bakışları; yabancı dil öğrenme istekleri, amaçları, ihtiyaçları, önyargıları ve öğrenme ortamlarıyla oldukça yakından ilişkilidir.

Yabancı dil öğrenme sürecinde bireylerin önyargıları ve kalıplaşmış olumsuz düşünceleri de dil öğrenme başarısına etki eden faktörler arasındadır. Ünal (2015), kalıplaşmış düşüncelerin bazı insanlar tarafından doğru olup olmadığına bakılmadığını ve insanların bu düşüncelerini değiştirmeye yönelmeden her türlü yeni bilgiden uzak durduklarını ifade etmektedir. Hâl böyle olunca genelde eğitimin her alanında özelde ise yabancı dil eğitiminde birtakım engellerin ortaya çıması kaçınılmazdır. Yabancı dil öğrenme amaçlarının tam olarak belirlenmesi ve yabancı dil algı ve bakış açılarının ortaya konulması yabancı dil eğitiminin niteliğini artırma noktasında eğitimcilere yol gösterebilir.

Alanyazında yer bulan ve yabancı dil öğrenme sürecinde etkisi tartışılan bir diğer değişken de cinsiyettir. Son yıllarda yapılan araştırmalarda yabancı dil öğrenme inanç ve algılarında cinsiyetin rolü üzerinde durulan konulardan birisidir. Örneğin, Durmuşçelebi, Bozgeyikli, ve Çetinkaya (2018) lise öğrencilerinin dil öğrenme inançlarını inceledikleri çalışmalarında; öğrencilerin dil öğrenme inançları, öğrenen özerklikleri ve akademik başarılarının cinsiyet değişkenine göre farklılaştığı sonucuna varmışlardır. Çalışmada kadın öğrencilerin dil öğrenme inançlarının erkek öğrencilere göre daha yüksek olduğu belirtilmiştir. Aynı şekilde bir diğer çalışmada Kuşçu (2018) cinsiyetin dil öğrenme profilleri üzerinde etkisi olup olmadığını araştırmıştır. Yazar, araştırma sonucunda kadın öğrencilerin yabancı dil öğrenme ölçeği puanlarının erkek öğrencilere göre daha yüksek olduğunu ve kadın öğrencilerin yabancı dili daha çok iletişim amaçlı kullandığını belirtmektedir. Bu çalışmaların dışında, ilgili alanyazın incelendiğinde cinsiyet değişkeninin yabancı dil öğrenmenin farklı boyutlarında anlamlı fark oluşturup oluşturmadığının araştırıldığı da görülmektedir (Aydın, 2006; Ünal \& Özdemir, 2008; Ayırır, Arıŏul \& Ünal, 2012; Yaman, 2012).

Tüm bu bahsedilenlerden hareketle bu çalışma öğrencilerin yabancı dile olan bakış açılarını ortaya çıkarmayı hedeflemektedir. Öğrencilerin yabancı dile olan tutumları, yabancı dil öğrenme sürecinde ana dile bakışları, temel dil becerileriyle ilgili algıları, yabancı dil öğrenme amaçları ve cinsiyetin dil öğrenme algıları üzerinde etkisi olup olmadığı çalışmada üzerinde durulan diğer konulardır. Bu çerçevede, araştırmanın problem cümleleri ve alt problemleri aşağıdaki şekilde oluşturulmuştur.

1. Üniversite öğrencilerinin yabancı dil öğrenimine ilişkin algıları ne yöndedir?

a) Üniversite öğrencilerinin Türkiye'de yabancı dil öğrenimine ilişkin algıları ne yöndedir? 
b) Üniversite öğrencilerinin yabancı dil becerilerinin öğrenilmesiyle ilgili algıları ne yöndedir?

c) Üniversite öğrencilerinin yabancı dil öğrenme sürecinde ana dili kullanımı konusundaki bakış açıları nelerdir?

2. Üniversite öğrencilerinin yabancı dil algıları ile cinsiyetleri arasında anlamlı bir fark var mıdır?

\section{Yöntem}

Araştırma nicel bir araştırma olup araştırmada geçmişte ya da hâlen var olan bir durumu var olduğu şekliyle betimlemeyi amaçlayan tarama modeli kullanılmıştır. Tarama modellerinde araştırmaya konu olan olay, nesne veya birey kendi koşulları içinde olduğu gibi tanımlanmaya çalışılır (Karasar, 2011). Araştırma yabancı dil olarak İngilizcenin yanında Almanca ve Fransızca dilleriyle ilgili de öğrencilerin algılarını belirlemeyi amaçladığından, katılımcılar belirlenirken amaçlı örnekleme yöntemi kullanılmıştır. Amaçlı örneklemede örneklem, evrenin özellikleri hakkındaki bilgiye dayanılarak ve araştırmanın amacına göre seçilir (Büyüköztürk, Akgün, Demirel, Karadeniz, \& Çakmak, 2015). Mevcut çalışmada araştırmaya katılan üniversite öğrencilerinin yabancı dile olan algısı ve bakış açıları ortaya konmaya çalışılmıştır.

\subsection{Katılımcilar}

Araştırmanın çalışma evrenini Türkiye'de üniversitelerin hazırlık ve birinci sınıflarına devam eden ve İngilizce, Almanca, Fransızcayı yabancı dil olarak öğrenen öğrenciler oluşturmaktadır. Araştırmanın örneklemini ise 2016-2017 eğitim öğretim yılında bir devlet üniversitesinde hazırlık ve birinci sinıflara devam eden ve yabancı dil olarak İngilizce, Almanca ve Fransızca öğrenen toplam 200 öğrenci oluşturmaktadır. Katılımcıların cinsiyet ve lisans programlarına ilişkin sayısal dağılımı aşağıdaki tabloda sunulmuştur;

Tablo 1. Katılımcıların Cinsiyet ve Lisans Programı Bazında Dağılımı

\begin{tabular}{lll}
\hline Lisans Programı & Kadın & Erkek \\
\hline Alman Dili Ĕ̆itimi & 22 & 10 \\
Fransız Dili Ĕ̆itimi & 18 & 9 \\
İngiliz Dili Ĕ̆itimi & 38 & 10 \\
İngilizce İktisat & 18 & 11 \\
Metalurji ve Malzeme Mühendisliği & 14 & 25 \\
Uçak ve Uzay Mühendisliği & 11 & 14 \\
Toplam & 121 & 79 \\
\hline
\end{tabular}

\subsection{Veri toplama aracı ve analizi}

Araştırmada veri toplamak için Baştürk (2012) tarafından geliştirilmiş yirmi madde içeren Likert tipi anket kullanılmıştır. Ankette öğrencilerden yirmi maddelik tek yargı içeren ifadelere, 1'den 5'e doğru giden kesinlikle katılıyorum, katılıyorum, kararsızım, katılmıyorum, kesinlikle katılmıyorum seçeneklerinden kendilerine uygun olanı işaretlemeleri istenmiştir. Toplanan veriler SPSS 20 programında önce güvenilirlik analizine tabii tutulmuştur. Anketin güvenilirlik katsayısı (Cronbach alfa) 0,76 olarak bulunmuştur. Bu değer anketin yeterince güvenilir olduğunu işaret etmektedir. Anketten elde edilen veriler analiz edilmeden önce verilerin normal dağılıp dağılmadığını kontrol etmek amacıyla basıklık ve çarpıklık değerleri incelenmiş ve Shapiro-Wilk testi yapılmıştır. Basıklık değeri - 
,015, çarpıklık değeri ise ,335 olarak bulunmuştur. Shapiro-Wilk testi sonucuna göre ise anlamlılık değeri ,579 olarak bulunmuş ve verilerin normal dağıldığı sonucuna varılmıştır. Basıklık ve çarpıklık değerleri -1,5 ve +1.5 arasında olursa verilerin normal dağıldığı kabul edilmektedir (Tabachnick \& Fidell, 2013). Tüm bu analizlerden sonra yirmi madde için öğrencilerin verdiği cevapların frekans değerleri hesaplanmış, kadın ve erkek öğrencilerin yabancı dil algıları arasında fark olup olmadığını saptamak için ise bağımsız gruplar t-testi uygulanmıştır.

\section{Bulgular}

Anketin alt boyutları; yabancı dil öğrenmede amaç, Türkiye'de yabancı dil öğrenimine olan genel bakış açısı, yabancı dil öğrenme süreci ve temel dil becerilerine yönelik bakış açısı, yabancı dil öğreniminde Türkçenin etkisi ve yabancı dil öğrenmeye karşı olumlu bakış şeklinde incelenmiş ve sonuçlar bu doğrultuda değerlendirilmiştir. Katılımcıların yabancı dil öğrenmedeki amacını sorgulayan ilk maddeye verilen cevaplar aşağıdaki tabloda incelenmiştir.

Tablo 2. Yabancı Dil Öğrenmede Amaç

\begin{tabular}{|c|c|c|c|c|c|c|c|c|c|c|c|}
\hline Madde & & \multicolumn{2}{|c|}{$\begin{array}{l}\text { Kesinlikle } \\
\text { Katıllyorum }\end{array}$} & \multicolumn{2}{|c|}{ Katıllyorum } & \multicolumn{2}{|c|}{ Kararsızım } & \multicolumn{2}{|c|}{ Katılmiyorum } & \multicolumn{2}{|c|}{$\begin{array}{l}\text { Kesinlikle } \\
\text { Katılmıyorum }\end{array}$} \\
\hline $\begin{array}{l}\text { Yabancı } \\
\text { bulmak }\end{array}$ & iş & $\mathrm{n}$ & $\%$ & $\mathrm{n}$ & $\%$ & $\mathrm{n}$ & $\%$ & $\mathrm{n}$ & $\%$ & $\mathrm{n}$ & $\%$ \\
\hline içın ogreniyorum. & & 58 & 29 & 72 & 36 & 17 & 8,5 & 37 & 18,5 & 16 & 8 \\
\hline
\end{tabular}

Tablo 2'de görüldüğü üzere araştırmaya katılan öğrencilerin yarısından çoğu (\% 65) yabancı dili iş bulmak amacıyla öğrendiğini söylemiştir. Öğrencilerin yaklaşık \% 27'si yabancı dil öğrenmede amaçlarının iş bulmak olmadığını beyan etmiştir. Bu sonuçlardan ankete katılan üniversite öğrencilerinin çoğunluğunun motivasyonunun dış kaynaklı olduğu ve yabancı dil öğrenmeye olan bakışlarının gelecekte iş bulma kaygısıyla şekillendiği söylenebilir. Bu noktadan hareketle öğrencilerin dışsal motivasyonunun yanında içsel motivasyonlarını da artırmanın yolları araştırılmalı ve yabancı dili sadece iş bulma amaçlı değil gerçekten istedikleri için öğrenmelerini sağlayacak bakış açısı kazandırmak için tedbir alınmalıdır.

Katılımcıların Türkiye'de dil öğrenimine olan genel bakışının sayısal verilerle açıklandığı Tablo 3'de görüldüğü gibi, Türkiye'de yabancı dilin sınıf ortamında öğrenilebilmesine ilişkin katılımcı yorumlarında kararsızlar \% 40 oranındadır. Bu görüşe katılan öğrencilerin oranı \% 39, katılmayanların oranı ise \% 21'dir. Öğrencilerin yabancı dilin sınıf ortamında öğrenilmesine karşı genellikle kararsız kalmaları sınıf ortamında dil öğrenilebileceğine ilişkin zihinlerinde soru işaretleri bulunduğu ve tam olarak olumlu bir algıya sahip olmadıklarını göstermektedir.

Tablo 3. Türkiye'de Yabancı Dil Öğrenimine olan Genel Bakış Açısı

\begin{tabular}{|c|c|c|c|c|c|c|c|c|c|c|}
\hline \multirow{3}{*}{$\begin{array}{l}\text { Madde } \\
\text { Türkiye'de } \quad \text { öğrenciler } \\
\text { öğrendikleri yabancı dili } \\
\text { sinıf } \quad \text { ortamında } \\
\text { öğrenebilirler. }\end{array}$} & \multicolumn{2}{|c|}{$\begin{array}{l}\text { Kesinlikle } \\
\text { Katılıyorum }\end{array}$} & \multicolumn{2}{|c|}{ Katılıyorum } & \multicolumn{2}{|c|}{ Kararsızım } & \multicolumn{2}{|c|}{ Katılmıyorum } & \multicolumn{2}{|c|}{$\begin{array}{l}\text { Kesinlikle } \\
\text { Katılmiyorum }\end{array}$} \\
\hline & $\mathrm{n}$ & $\%$ & $\mathrm{n}$ & $\%$ & $\mathrm{n}$ & $\%$ & $\mathrm{n}$ & $\%$ & $\mathrm{n}$ & $\%$ \\
\hline & 21 & 10,5 & 57 & 28,5 & 80 & 40 & 29 & 14,5 & 13 & 6,5 \\
\hline $\begin{array}{l}\text { Türkiye'de yabancı dil çok } \\
\text { iyi öğretiliyor. }\end{array}$ & $\mathrm{n}$ & $\%$ & $\mathrm{n}$ & $\%$ & $\mathrm{n}$ & $\%$ & $\mathrm{n}$ & $\%$ & $\mathrm{n}$ & $\%$ \\
\hline
\end{tabular}




51

25,5

58

Aynı şekilde Türkiye'de yabancı dilin çok iyi öğretildiği maddesine, katılımcıların çoğunluğu (\% 65’e yakın) olumsuz görüş bildirmiştir. Sadece \% 12 oranında katılımcı bu konuda olumlu bakış açısına sahiptir. Bu sonuçla üniversite öğrencilerinin Türkiye'de yabancı dil öğretilmesi konusunda genel olarak iyimser olmayan bir bakış açısına sahip oldukları görülmektedir. Bu bakış açısının yabancı dil öğrenme başarısı noktasında öğrencileri olumsuz etkileyeceği aşikârdır.

Yabancı dil öğrenme süreci ve temel dil becerilerine yönelik bakış açısına ilişkin olarak aşağıda verilen tabloda da görüleceği üzere, konuşma becerisinde zorluk çektiğini beyan eden öğrenci oranı \% 65 olup yazma (\% 32) ve anlamada (\% 19,5) zorluk çektiğini beyan eden öğrencilerden bir hayli fazladır. Bu da malumun ilamı niteliğinde bir doğrulama olup Türkiye'de yabancı dili üretme noktasındaki sıkıntıların bir yansımasıdır. Yabancı dil öğrenme sürecinde hata düzeltmeyle ilgili olarak katılımcıların \% 70’i gibi büyük bir çoğunluğu öğretmenin yapılan hataları hemen düzeltmesi gerektiğini söylemişlerdir. Bu görüşe katılmayanların oranı \% 12'de kalmıştır.

Tablo 4. Yabancı Dil Öğrenme Süreci ve Temel Dil Becerilerine Yönelik Bakış Açısı

\begin{tabular}{|c|c|c|c|c|c|c|c|c|c|c|}
\hline \multirow{3}{*}{$\begin{array}{l}\text { Madde } \\
\text { Yabancı dili öğrenmede } \\
\text { en çok konuşmada zorluk } \\
\text { çekiyorum. }\end{array}$} & \multicolumn{2}{|c|}{$\begin{array}{l}\text { Kesinlikle } \\
\text { Katılyyorum }\end{array}$} & \multicolumn{2}{|c|}{ Katılyyorum } & \multicolumn{2}{|c|}{ Kararsızım } & \multicolumn{2}{|c|}{ Katılmıyorum } & \multicolumn{2}{|c|}{$\begin{array}{l}\text { Kesinlikle } \\
\text { Katılmıyorum }\end{array}$} \\
\hline & $\mathrm{n}$ & $\%$ & $\mathrm{n}$ & $\%$ & $\mathrm{n}$ & $\%$ & $\mathrm{n}$ & $\%$ & $\mathrm{n}$ & $\%$ \\
\hline & 71 & 35,5 & 59 & 29,5 & 28 & 14 & 28 & 14 & 14 & 7 \\
\hline \multirow{2}{*}{$\begin{array}{l}\text { Yabancı dilde yazmada } \\
\text { güçlük çekiyorum. }\end{array}$} & $\mathrm{n}$ & $\%$ & $\mathrm{n}$ & $\%$ & $\mathrm{n}$ & $\%$ & $\mathrm{n}$ & $\%$ & $\mathrm{n}$ & $\%$ \\
\hline & 10 & 5 & 54 & 27 & 51 & 25,5 & 64 & 32 & 21 & 10,5 \\
\hline \multirow{2}{*}{$\begin{array}{l}\text { Yabancı dili anlamada } \\
\text { güçlük çekiyorum. }\end{array}$} & $\mathrm{n}$ & $\%$ & $\mathrm{n}$ & $\%$ & $\mathrm{n}$ & $\%$ & $\mathrm{n}$ & $\%$ & $\mathrm{n}$ & $\%$ \\
\hline & 9 & 4,5 & 30 & 15 & 45 & 22,5 & 80 & 40 & 36 & 18 \\
\hline \multirow{2}{*}{$\begin{array}{lr}\text { Yabancı dil } & \text { öğrenirken } \\
\text { öğretmen } & \text { yapılan } \\
\text { yanlışları } & \text { hemen } \\
\text { düzeltmelidir. } & \end{array}$} & $\mathrm{n}$ & $\%$ & $\mathrm{n}$ & $\%$ & $\mathrm{n}$ & $\%$ & $\mathrm{n}$ & $\%$ & $\mathrm{n}$ & $\%$ \\
\hline & 69 & 34,5 & 72 & 36 & 35 & 17,5 & 17 & 8,5 & 7 & 3,5 \\
\hline
\end{tabular}

Tablo 4'deki sonuçlara göre Türkiye'de yabancı dilde konuşma ve yazma gibi üretimsel becerilerdeki sorun katılımcılar tarafından da teyit edilmiştir. Yabancı dil hakkında bir klişe haline gelmiş 'Anlıyorum ama konuşamıyorum.' ifadesi de yabancı dili anlamada güçlük çekmeye ilişkin maddeye verilen \% $58^{\prime}$ 'lik katılmama oranıyla bir kez daha doğrulanmıştır. Bu çerçevede katılımcılar tarafından olumsuz algı ve bakış açısı geliştirilen konuşma ve yazma becerilerine özel önem verilmeli ve bu becerilere ilişkin önyargı ve olumsuz algı mümkün olduğunca en aza indirilmelidir.

Araştırmanın bir başka boyutunu oluşturan Yabancı dil öğreniminde Türkçenin etkisine yönelik katılımcı görüşleri Tablo 5'de sunulmuştur. Yabancı dil öğrenirken Türkçeden yararlandıklarını beyan edenlerin oranı \% 76,5’tir. Bu görüşe katılmayanların oranı ise \% 13 'tür. Türkçe sözlük kullanımına ilişkin olarak katılımcıların \% 56'sı olumlu görüş bildirmiş, \% 33,5 ise tek dilli sözlüklerden yararlandıklarını beyan etmiştir. Türkçe açıklamalı gramer kitaplarından yabancı dili öğrenmediğini 
söyleyenlerin oranı \% 55,5 olarak bulunmuştur. Bir diğer maddede sorulan öğretmenin Türkçe konuşmasına ilişkin katılımcıların \% 24'ü olumsuz etkiye neden olduğunu söylemiştir. Ancak katılımcılarının \% 53’ü yabancı dil öğrenme sürecinde öğretmenin Türkçe konuşmasının dil gelişimlerinde herhangi bir olumsuz etki yapmadığını belirtmişlerdir.

Tablo 5. Yabancı Dil Öğreniminde Türkçe’nin Etkisi

\begin{tabular}{|c|c|c|c|c|c|c|c|c|c|c|}
\hline \multirow{3}{*}{$\begin{array}{l}\text { Madde } \\
\text { Yabancı dili öğrenirken } \\
\text { Türkçeden } \\
\text { yararlanıyorum. }\end{array}$} & \multicolumn{2}{|c|}{$\begin{array}{l}\text { Kesinlikle } \\
\text { Katıllyorum }\end{array}$} & \multicolumn{2}{|c|}{ Katilyyorum } & \multicolumn{2}{|c|}{ Kararsızım } & \multicolumn{2}{|c|}{ Katılmıyorum } & \multicolumn{2}{|c|}{$\begin{array}{l}\text { Kesinlikle } \\
\text { Katilyyorum }\end{array}$} \\
\hline & $\mathrm{n}$ & $\%$ & $\mathrm{n}$ & $\%$ & $\mathrm{n}$ & $\%$ & $\mathrm{n}$ & $\%$ & $\mathrm{n}$ & $\%$ \\
\hline & 62 & 31 & 91 & 45,5 & 21 & 10,5 & 21 & 10,5 & 5 & 2,5 \\
\hline \multirow{2}{*}{$\begin{array}{l}\text { Yabancı dilde sözcükleri } \\
\text { öğrenirken Türkçe sözlük } \\
\text { kullanıyorum. }\end{array}$} & $\mathrm{n}$ & $\%$ & $\mathrm{n}$ & $\%$ & $\mathrm{n}$ & $\%$ & $\mathrm{n}$ & $\%$ & $\mathrm{n}$ & $\%$ \\
\hline & 45 & 22,5 & 67 & 33,5 & 21 & 10,5 & 41 & 20,5 & 26 & 13 \\
\hline \multirow{2}{*}{$\begin{array}{l}\text { Yabancı dili } \\
\text { açılamalı } \\
\text { kitaplarından } \\
\text { öğreniyorum. }\end{array}$} & $\mathrm{n}$ & $\%$ & $\mathrm{n}$ & $\%$ & $\mathrm{n}$ & $\%$ & $\mathrm{n}$ & $\%$ & $\mathrm{n}$ & $\%$ \\
\hline & 23 & 11,5 & 38 & 19 & 28 & 14 & 71 & 35,5 & 40 & 20 \\
\hline \multirow{2}{*}{$\begin{array}{lr}\text { Yabancı dil } & \text { eğitiminde } \\
\text { öğretmenin } & \text { Türkçe } \\
\text { konuşması } & \text { benim dil } \\
\text { gelişimimi } & \text { olumsuz } \\
\text { etkiliyor. } & \end{array}$} & $\mathrm{n}$ & $\%$ & $\mathrm{n}$ & $\%$ & $\mathrm{n}$ & $\%$ & $\mathrm{n}$ & $\%$ & $\mathrm{n}$ & $\%$ \\
\hline & 16 & 8 & 32 & 16 & 46 & 23 & 57 & 28,5 & 49 & 24,5 \\
\hline \multirow{2}{*}{$\begin{array}{l}\text { Yabancı dili öğrenirken } \\
\text { yaptığım hatalar Türkçe } \\
\text { düşünmemden } \\
\text { kaynaklanıyor. }\end{array}$} & $\mathrm{n}$ & $\%$ & $\mathrm{n}$ & $\%$ & $\mathrm{n}$ & $\%$ & $\mathrm{n}$ & $\%$ & $\mathrm{n}$ & $\%$ \\
\hline & 49 & 24,5 & 61 & 30,5 & 54 & 27 & 22 & 11 & 14 & 7 \\
\hline \multirow{2}{*}{$\begin{array}{l}\text { Yabancı dili } \\
\text { öğrendiğim } \\
\text { öğreniyorum. }\end{array}$} & $\mathrm{n}$ & $\%$ & $\mathrm{n}$ & $\%$ & $\mathrm{n}$ & $\%$ & $\mathrm{n}$ & $\%$ & $\mathrm{n}$ & $\%$ \\
\hline & 8 & 4 & 30 & 15 & 50 & 25 & 73 & 36,5 & 39 & 19,5 \\
\hline \multirow{2}{*}{$\begin{array}{l}\text { Yabancı dil öğrenirken } \\
\text { Türkçe } \\
\text { yapılmalıdır. }\end{array}$} & $\mathrm{n}$ & $\%$ & $\mathrm{n}$ & $\%$ & $\mathrm{n}$ & $\%$ & $\mathrm{n}$ & $\%$ & $\mathrm{n}$ & $\%$ \\
\hline & 35 & 17,5 & 94 & 47 & 45 & 22,5 & 22 & 11 & 4 & 2 \\
\hline
\end{tabular}

Yapılan hataların Türkçe düşünmeden kaynaklandığını beyan eden katılımcıların oranı \% 55, bu görüşe katılmayanların oranı ise \% 18 olarak bulunmuştur. Yabancı dili Türkçe öğrendiği gibi öğrendiğini söyleyen katılımcıların oranı \% 19, katılmayanların oranı ise \% 56 olarak belirlenmiştir. Yabancı dil öğrenirken Türkçe açıklama yapılması noktasında katılımcıların büyük çoğunluğu (\% 64) olumlu görüş bildirmiş sadece \% 12 öğrenci Türkçe açılklamaya karşı çıkmıştır.

Tüm bu oranlar değerlendirildiğinde yabancı dil öğrenirken Türkçeden yararlandıklarını, Türkçe açıklama yapılması gerektiğini ve öğretmenin de sınıfta Türkçe kullanmasını söyleyenlerin oranı oldukça yüksektir. Ancak katılımcıların bir yandan Türkçe düşünmenin olumsuz etkilerine vurgu yapması diğer yandan Türkçe kullanımına ilişkin olumlu bakışları bir tutarsızlı̆̆ı da göstermektedir. Bu tutarsızlı̆̆a rağmen yabancı dil öğretiminde ana dilin kullanımı ve bilimsel çalışmalarda ifade edilen 
pedagojik faydaları düşünüldüğünde, katılımcıların bu olumlu algılarını fırsata dönüştürmek önem arz etmektedir.

Araştırmada son boyutu oluşturan ve Tablo 6'da sonuçları sunulan yabancı dil öğrenmeye karşı katılımcıların olumlu bakış açısı konusunda öğrencilerin \% 96'sı gibi büyük bir çoğunluğu motivasyonun önemine vurgu yapmıştır. Öte yandan katılımcıların \% 86'sı "Yabancı dil dilin konuşulduğu ülkede öğrenilir.” görüşünü savunmuşlardır. Bu sonuç da aslında Türkiye’de yabancı dilin öğrenilebileceği algısına olumsuz kaynak oluşturmaktadır. Olumsuz bakış açısının görüldüğü bir diğer maddede katılımcıların \% 56'sı yabancı dili istediği seviyede öğrenemediğini beyan etmiştir. Hedeflenen seviyeye ulaşma noktasında ise katılımcıların \% 62,5’i olumsuz görüş bildirmiştir.

Tablo 6. Yabancı Dil Öğrenmeye Karşı Olumlu Bakış

\begin{tabular}{|c|c|c|c|c|c|c|c|c|c|c|}
\hline \multirow{2}{*}{$\begin{array}{l}\text { Madde } \\
\text { Yabancı dili öğrenmede } \\
\text { motivasyon önemlidir. }\end{array}$} & \multicolumn{2}{|c|}{$\begin{array}{l}\text { Kesinlikle } \\
\text { Katılyyorum }\end{array}$} & \multicolumn{2}{|c|}{ Katılyyorum } & \multicolumn{2}{|c|}{ Kararsızım } & \multicolumn{2}{|c|}{ Katılmıyorum } & \multicolumn{2}{|c|}{$\begin{array}{l}\text { Kesinlikle } \\
\text { Katıllyorum }\end{array}$} \\
\hline & $\mathrm{n}$ & $\%$ & $\mathrm{n}$ & $\%$ & $\mathrm{n}$ & $\%$ & $\mathrm{n}$ & $\%$ & $\mathrm{n}$ & $\%$ \\
\hline & 160 & 80 & 33 & 16,5 & 5 & 2,5 & 2 & 1 & o & o \\
\hline \multirow{2}{*}{ 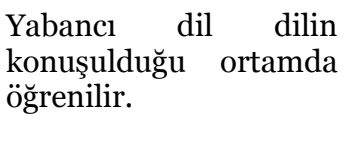 } & $\mathrm{n}$ & $\%$ & $\mathrm{n}$ & $\%$ & $\mathrm{n}$ & $\%$ & $\mathrm{n}$ & $\%$ & $\mathrm{n}$ & $\%$ \\
\hline & 129 & 64,5 & 43 & 21,5 & 12 & 6 & 13 & 6,5 & 3 & 1,5 \\
\hline \multirow{2}{*}{$\begin{array}{l}\text { Yabancı dili istediğim } \\
\text { seviyede } \\
\text { öğrenebiliyorum. }\end{array}$} & $\mathrm{n}$ & $\%$ & $\mathrm{n}$ & $\%$ & $\mathrm{n}$ & $\%$ & $\mathrm{n}$ & $\%$ & $\mathrm{n}$ & $\%$ \\
\hline & 8 & 4 & 30 & 15 & 50 & 25 & 73 & 36,5 & 39 & 19,5 \\
\hline \multirow{2}{*}{$\begin{array}{l}\text { Yabancı dil öğrenmede } \\
\text { istediğim } \\
\text { geldim. }\end{array}$} & $\mathrm{n}$ & $\%$ & $\mathrm{n}$ & $\%$ & $\mathrm{n}$ & $\%$ & $\mathrm{n}$ & $\%$ & $\mathrm{n}$ & $\%$ \\
\hline & 2 & 1 & 17 & 8,5 & 56 & 28 & 85 & 42,5 & 40 & 20 \\
\hline \multirow{2}{*}{$\begin{array}{l}\text { Herkes yabancı dil } \\
\text { öğrenebilir. }\end{array}$} & $\mathrm{n}$ & $\%$ & $\mathrm{n}$ & $\%$ & $\mathrm{n}$ & $\%$ & $\mathrm{n}$ & $\%$ & $\mathrm{n}$ & $\%$ \\
\hline & 79 & 39,5 & 53 & 26,5 & 23 & 11,5 & 25 & 12,5 & 20 & 10 \\
\hline \multirow{2}{*}{$\begin{array}{l}\text { Yabancı dili } \\
\text { ortamında } \\
\text { öğreniyorum. }\end{array}$} & $\mathrm{n}$ & $\%$ & $\mathrm{n}$ & $\%$ & $\mathrm{n}$ & $\%$ & $\mathrm{n}$ & $\%$ & $\mathrm{n}$ & $\%$ \\
\hline & 65 & 32,5 & 83 & 41,5 & 33 & 16,5 & 13 & 6,5 & 6 & 3 \\
\hline
\end{tabular}

$\mathrm{Bu}$ olumsuz bakış açlarına rağmen herkesin yabancı dil öğrenebileceği maddesinde katılımcıların \% 66'sı olumlu, \% 11,5 kararsız, \% 22,5’i ise olumsuz beyanda bulunmuştur. Bu sonuç genel yabancı dil öğrenme algısı çerçevesinde olumlu olarak değerlendirilmektedir. Bu boyuttaki bir diğer madde yabancı dil öğrenmede sınıf ortamını sorgulamaktadır. Türkiye'de bir yabancı dilin ikinci dil olarak değil de gerçek anlamda yabancı dil olarak öğretilme zorunluluğu ve öğrencilerin sınıf ortamı dışında yabancı dili kullanabilecek imkânlarının son derece sınırlı olması nedeniyle katılımcıların \% 74'ünün yabancı dili sınıf ortamında öğrendiklerini beyan etmeleri tesadüf değildir. Katılımcıların sadece \% 9'u yabancı dili sınıf ortamı dışında öğrendiklerini söylemişlerdir.

Araştırmanın ikinci problem cümlesi olan üniversite öğrencilerinin yabancı dil algıları ile cinsiyetleri arasında anlamlı bir fark olup olmadığı durumu, bağımsız gruplar t-testi kullanarak analiz edilmeye 
çalışılmıştır. Tablo 7’de görüldüğü üzere yabancı dil algıları konusunda kadın ve erkek öğrenciler arasında istatistiksel olarak anlamlı bir fark bulunmamıştır. Maddelere verilen cevapların ortalamalarına bakıldığında; kadın üniversite öğrencileri 2,63, erkek üniversite öğrencileri ise 2,73 ortalamalarla birbirlerine çok yakın cevaplar vermişlerdir.

Tablo 7. Cinsiyet Değişkeni için Bağımsız Gruplar T-Testi Sonuçları

\begin{tabular}{lcccc}
\hline Cinsiyet & N & Mean & SD & p \\
\hline Kadin & 121 & 2,63 &, 338 & \\
Erkek & 79 & 2,73 &, 377 & \\
\hline
\end{tabular}

${ }^{*} \mathrm{p}>, 05$

Maddeler tek tek analiz edildiğinde sadece dört maddede kadın ve erkek üniversite öğrencilerin verdikleri cevaplar arasında anlamlı farklılıklar bulunmuştur. Anketin ikinci maddesinde yabancı dil öğrenirken Türkçeden yararlanma durumu sorulmuş ve bu maddeye kadın öğrenciler 1,94, erkek öğrenciler ise 2,29 ortalamayla cevap vermişlerdir. Bu sonuçlar kadın öğrencilerin yabancı dil öğrenirken Türkçeden yararlanmaya daha eğilimli olduklarını göstermektedir. Aynı şekilde altıncı maddede sorgulanan yabancı dil öğrenmede motivasyonun önemliliği, yedinci maddede yabancı dilin konuşulduğu ortamlarda öğrenilme durumu ve on ikinci maddede yabancı dil öğrenmede en çok konuşmada zorluk çekilmesine dair bulgularda da kadın ve erkek öğrencilerin cevapları arasında anlamlı farklılıklar bulunmuştur. İlgili veriler Tablo 8' de sunulmuştur.

Tablo 8. Madde Bazında Bağımsız Gruplar T-Test Sonuçları

\begin{tabular}{|c|c|c|c|c|}
\hline Madde & Cinsiyet & $\mathbf{N}$ & Mean & $\mathbf{p}$ \\
\hline $\begin{array}{l}\text { 2. Yabancı dili } \\
\text { öğrenirken Türkçeden }\end{array}$ & Kadın & 121 & 1,94 & \multirow{2}{*}{,002 } \\
\hline yararrantyorum. & Erkek & 79 & 2,29 & \\
\hline 6. Yabancı dil & Kadın & 121 & 1,17 & \multirow[b]{2}{*}{, ooc } \\
\hline $\begin{array}{l}\text { öğrenmede motivasyon } \\
\text { önemlidir. }\end{array}$ & Erkek & 79 & 1,37 & \\
\hline 7. Yabancı dil & Kadın & 121 & 1,71 & \multirow[b]{2}{*}{,002 } \\
\hline $\begin{array}{l}\text { konuşulduğu ortamda } \\
\text { öğrenilir. }\end{array}$ & Erkek & 79 & 1,41 & \\
\hline $\begin{array}{lrr}\text { 12. Yabancı } & \text { dili } \\
\text { öğrenmede } & \text { en } & \text { çok } \\
\text { konuşmada } & & \text { zorluk } \\
\text { çekiyorum. } & & \end{array}$ & Erkek & 121 & 2,68 & ,004 \\
\hline
\end{tabular}

Tablodan da görüleceği üzere kadın öğrenciler yabancı dil öğrenmede motivasyonu erkek öğrencilere göre daha önemli bulmuşlardır. Yabancı dilin konuşulduğu ülkede öğrenilmesi durumu ise erkek öğrenciler tarafından daha fazla desteklenmiştir. Yabancı dili öğrenmede en çok konuşma becerisinde zorluk çektiklerini belirten taraf ağırlıklı olarak kadın öğrenciler olmuştur. İstatistiksel olarak yabancı 
dil öğrenme algılarında bu dört madde dışında kadın ve erkek öğrenciler arasında anlamlı bir farklılık bulunmamıştır.

\section{Sonuç ve değerlendirme}

Üniversite öğrencilerinin Türkiye'de yabancı dile bakış açılarının ortaya çıarılmasını hedefleyen bu çalışmaya 2016-2017 akademik ylında bir devlet üniversitesinin farklı lisans programlarında hazırlık ve birinci sınıflarında öğrenim gören 200 öğrenci katılmıştır. Araştırmada daha önce Baştürk (2012) tarafından uygulanan Likert tipi anket kullanılmıştır. Toplanan verilerin SPSS 20 programında betimleyici istatistikleri çıkarılmıştır. Toplam beş boyuttan oluşan araştırmada üniversite öğrencilerinin yabancı dile olan genel bakışı, yabancı dil öğreniminde ana dili kullanımına yönelik algıları, temel dil becerilerine olan bakış açıları, yabancı dil öğrenmede amaç ve olumlu tutumlarının olup olmadığı değerlendirilmiştir. Ayrıca araştırmada, kadın ve erkek öğrencilerin yabancı dil algılarında anlamlı fark olup olmadığı sorusuna da cevap aranmıştır.

Araştırma sonucunda üniversite öğrencilerinin büyük çoğunluğunun genel anlamda yabancı dile karşı olumlu bakış açısının olduğu, yabancı dili büyük oranda sınıf ortamında öğrendikleri, yabancı dil öğrenme sürecinde mümkün olduğunca Türkçeden yararlanma eğiliminde oldukları ve dil öğrenme motivasyonunu önemsedikleri ortaya çıkmıştır. Bunlara ek olarak araştırma sonucunda özellikle yabancı dilde konuşma ve yazma becerilerine karşı öğrencilerin önyargılı olup olumsuz bakış açısı geliştirdikleri belirlenmiştir; ayrıca araştırmaya katılan öğrencilerin yarısından fazlasının yabancı dili öğrenmede dışsal motivasyona sahip oldukları sonucuna varılmıştır. Kadın ve erkek öğrenciler arasında yabancı dil öğrenme algıları bağlamında herhangi bir anlamlı fark bulunmamıştır.

Araştırmanın bulgularından hareketle; Türkiye'de ilkokul ikinci sınıftan üniversite eğitimine kadar verilen yabancı dil eğitimi göz önüne alındığında, eğitim hayatlarının son kademesindeki öğrencilerin dile bakış açısı, verilen eğitimin niteliği ve öğrencilerin yabancı dille ilgili inanç, kaygı ve önyargıların yabancı dil eğitim süreçlerinin planlanmasında etkili rol oynaması gerektiği açıktır. Daha önce bahsedildiği gibi yabancı dil öğrenme sorunlarının başında motivasyon eksikliği ve dile karşı önyargı gelmektedir. Öğrencilerin bakış açılarının dil öğretim politikalarına yansıtılması, inanç ve tutumlarının değerlendirilmesi ve bunların önceden belirlenmesi uzun ylllar boyunca süren bu eğitim sürecinden daha fazla verim alınmasını sağlayacaktır. Özellikle ülkemizde yabancı dile olan olumsuz önyargıyı daha sürecin başından itibaren engellemek için yabancı dil öğretim programlarında çok önemli değişiklikler yapılmıştır. Örneğin, 2018 yılı başında uygulamaya konulan 2. sınıf İngilizce Öğretim Programında gerek sözcük gerekse yapı çeşitleri en az seviyede tutulmuş ve bilinenden bilinmeyene doğru bir süreç izlenmiştir. Bunun temel sebebi, öğrencilere yaptırılan etkinliklerle İngilizceyi sevdirerek motivasyonlarını ve dile olan ilgilerini artırmaktır (MEB, 2018).

Daha önce yapılmış çalışmalarda (Akalın \& Zengin, 2007; Baştürk, 2012; Karahan, 2007) olduğu gibi mevcut çalışmada da katılımcıların yabancı dile karşı olumlu bir bakışı olduğu ortaya çıkmıştır; ancak bu olumlu bakış doğru dil politikalarıyla desteklenmez ve öğrencilerin yabancı dile karşı inançları ve tutumları eğitim programlarına yansıtılmazsa bu olumlu bakış zamanla önyargıya dönüşüp yabancı dil eğitim sürecine zararlar verebilir.

Mevcut araştırma sadece bir devlet üniversitesindeki farklı lisans programlarında öğrenim gören üniversite öğrencileriyle sınırlıdır ve elbette ki tüm dil öğrenenlere genellenemez; ancak çalışma, ülkemizde en fazla öğrenilen ve öğretilen İngilizce dilinin haricinde Almanca ve Fransızca dil 
öğrencilerini de kapsadığından ve farklı lisans programlarından öğrencileri örneklem aldığından bütünle ilgili önemli ipuçları sunabilecek verileri içermektedir. Bu çerçevede daha fazla katılımcı ve daha farklı eğitim düzeylerinden öğrencilerin dâhil edilmesiyle yapılacak çalışmalar da alana katkı sağlayabilir.

\section{Kaynakça}

Acat, B. M., \& Demiral, S. (2002). Türkiyede yabancı dil öğreniminde motivasyon kaynakları ve sorunları. Kuram ve Uygulamada Egitim Yönetimi Dergisi, 8(3), 312-329.

Akalın, S., \& Zengin, B. (2007). Türkiye'de halkın yabancı dil ile ilgili algıları. Journal of Language and Linguistic Studies, 3(1), 181-200.

Arslan, M. \& Akbarov, A. (2010). Türkiye'de yabancı dil öğretiminde motivasyon-yöntem sorunu ve çözüm önerileri. Selçuk Üniversitesi, Edebiyat Fakültesi Dergisi. 24, 179-191.

Aydın, S. (2006). İkinci Dil Olarak İngilizce Öğrenimindeki Başarı Düzeyinin Bazı Değişkenlere Göre İncelenmesi. Atatürk Üniversitesi Sosyal Bilimler Enstitüsü Dergisi, 8(2), 273-285.

Ayırır, İ. O., Arıŏgul, S., \& Ünal, D. Ç. (2012). Cinsiyetin Ve Öğrenim Alanlarının Hazırlık Öğrencilerinin Yabancı Dil Öğrenme Stratejisi Kullanımına Etkisi. Hacettepe Üniversitesi Eğitim Fakültesi Dergisi, 42(42).

Babanoğlu, M. P., \& Ağçam, R. (2016). Learner perceptions on EFL teaching practices in Turkish higher education. Turkish Journal of Education, 5(3), 119-129.

Baştürk, M. (2012). İkinci Dil Öğrenme Algılarının Belirlenmesi: Balıkesir Örneği. Balikesir University Journal Of Social Sciences Institute, 15(28-1), 251-270.

Bayraktaroğlu, S. (2012). Neden yabancı dil eğitiminde başaralı olamıyoruz? İçinde A. Sarıçoban ve H. Öz (Eds.), Türkiye'de Yabancı Dil Eğitiminde Ĕ̆ilim Ne olmah? (9-14). Ankara: Hacettepe Üniversitesi.

Bayyurt, Y. (2012). 4+4+4 Eğitim sisteminde erken yaşta yabancı dil eğitimi. İçinde A. Sarıçoban ve H. Öz (Eds.), Türkiye'de Yabancı Dil Ĕ̆itiminde Eğilim Ne olmah? (1-7). Ankara: Hacettepe Üniversitesi Yayınları.

Breen, M. P. (Ed.). (2001). Learner contributions to language learning: New directions in research. Essex: Pearson Education Limited.

Büyüköztürk, Ş., Akgün, Ö. E., Demirel, F., Karadeniz, Ş., \& Çakmak, E. K. (2015). Bilimsel araşttrma yöntemleri. Pegem Akademi.

Can, E. \& Işık Can, C. (2014). Türkiye'de ikinci yabancı dil öğretiminde karşılaşılan sorunlar. Trakya Üniversitesi Eğitim Fakültesi Dergisi, 4(2), 43-63.

Çimen, B. A. (2017). Challenges in EFL Education in Turkey and Potential Solutions from the TertiaryLevel Instructors' Perspectives. International Journal of Language Academy, 5(6), 213-228.

Demirpolat, B. C. (2015). Türkiye’nin yabancı dil öğretimiyle imtihanı: Sorunlar ve çözüm önerileri. SETA. http://file.setav.org/Files/Pdf/20150707131308_131_yabancidil_we b.pdf Accessed on 28.04.2018.

Durmuşçelebi, M., Bozgeyikli, H., \& Çetinkaya, M. (2018). Lise Öğrencilerinin Dil Öğrenme İnançları ve Ögrenen Özerkliğinin Akademik Başarı Açısından İncelenmesi. OPUS-Uluslararası Toplum Araştırmaları Dergisi, 8, 248-262.

Ekmekçi, Ö. (1983). Yabancı dil öğretimi ve sorunları: Yabancı dil öğretiminde psiko-sosyal etmenler. Türk Ĕ̆itim Derneği Bilim Dizisi, Ankara: Şafak Matbaası.

Haznedar B. (2010), Türkiye'de Yabancı Dil Eğitimi: Reformlar, Yönelimler ve Öğretmenlerimiz. ICONTE International Conference on New Trends in Education and Their Implications 11-13 November, 2010 Antalya-Turkey 
Haznedar, B. (2004). Türkiye'de yabancı dil öğretimi: ilköğretim yabancı dil programı. Boğaziçi Üniversitesi Ĕ̆itim Dergisi, 21(2).

Horwitz, E. K. (1986). Preliminary evidence for the reliability and validity of a foreign language anxiety scale. TESOL Quarterly, 20, 559-562.

Işık, A. (2008). Yabancı dil eğitimimizdeki yanlışlar nereden kaynaklanıyor?. Journal of Language and Linguistic Studies, 4(2), pp-15.

Kaçar, I. G., \& Zengin, Z. (2009). İngilizceyi yabancı dil olarak öğrenenlerin dil öğrenme ile ilgili inançları, öğrenme yöntemleri, dil öğrenme amaçları ve öncelikleri arasındaki ilişki: Öğrenci boyutu. Journal of Language and Linguistic Studies, 5(1), 55-89.

Karahan, F. (2007). Language attitudes of Turkish students towards the English language and its use in Turkish context. Çankaya Üniversitesi Fen-Edebiyat Fakültesi, Journal of Arts and Sciences, 7, $73-87$.

Karasar, N. (2011). Bilimsel Araştırma Yöntemi. Ankara: Nobel Akademik Yayıncılık.

Kizildag, A. (2009). Teaching English in Turkey: Dialogues with teachers about the challenges in public primary schools. International Electronic Journal of Elementary Education, 1(3), 188-201.

Kuşçu, E. (2018). Üniversite Öğrencilerinin İkinci Yabancı Dil Olarak Fransızca Öğrenme Profilleri: Pamukkale Üniversitesi Eğitim Fakültesi ve Fen-Edebiyat Fakültesi Örneği Learning Profiles of Undergraduate Students Taking French as A Second Foreign Language: Sample of Pamukkale University Faculty of Education and Faculty Letters and Science. Kastamonu Eğitim Dergisi, 26(1), 1 .

MEB (Milli Ĕ̆itim Bakanlığı) (2018). İngilizce Dersi Öğretim Programı (İlkokul ve Ortaokul 2, 3, 4, 5, 6, 7, ve 8. Sinuflar). Ankara: T.C. Milli Eğitim Bakanlığ

Paker, T. (2012). Türkiye'de Neden Yabancı Dil (İngilizce) Öğretemiyoruz ve Neden Öğrencilerimiz İletişim Kurabilecek Düzeyde İngilizce Öğrenemiyor?. Pamukkale Üniversitesi Eğitim Fakültesi Dergisi, 32(32), 89-94.

Pan, V. L., \& Akay, C. (2015). Eğitim Fakültesinde Yabancı Dil Dersi Alan Öğrencilerin Yabancı Dil Dersine Yönelik Tutumlarının ve Sınıf Kaygılarının İncelenmesi. Elektronik Sosyal Bilimler Dergisi, 14(55), 79-97.

Suna, Y., \& Durmuşçelebi, M. (2013). Türkiye'de Yabancı Dil Öğrenme-Öğretme Problemine İlişkin Yapılan Çalışmaların Derlemesi. OPUS-Türkiye Sosyal Politika ve Çalışma Hayatı Araştırmaları Dergisi, 3(5), 7-24.

Tabachnick and Fidell, 2013 B.G. Tabachnick, L.S. Fidell Using Multivariate Statistics (sixth ed.)Pearson, Boston (2013)

Ünal, M. (2015). Yabancı Dile Yönelik Kalıplaşmış Düşünce Ölçeği. International Journal of Eurasia Social Sciences, 6(19), 218-233.

Ünal, M., \& İlhan, E. (2017). A Case Study on the Problems and Suggestions in Foreign Language Teaching and Learning at Higher Education. Journal of Education and Training Studies, 5(6), 64-72.

Ünal, M., \& Özdemir, M. Ç. (2008). Eğitim Fakültelerinde Ortak Ders Olarak Okutulan Yabancı Dil Derslerinde Öğrencilerin Bilişsel Hazır bulunuşluk Düzeylerinin Akademik Başarıya Etkisi. Ahi Evran Üniversitesi Kırşehir Eğitim Fakültesi Dergisi, 9(1), 13-22.

Yaman, Ş. (2012). Students'belıefs In Language Learning: Area And Gender Variables Of Study. Humanities Sciences, 7(2), 83-92. 